Original Article (short paper)

\title{
Geographic Information System as an aid instrument for public policies and management of sports facilities and programs
}

\author{
Bruna Lindman Bueno ${ }^{1}$ (D), Leandro Carlos Mazzei $^{1}$ (D), Alcides José Scaglia ${ }^{1}$ (D), \\ Thomaz Chagas de Almeida ${ }^{1}$ \\ ${ }^{1}$ Universidade Estadual de Campinas, Limeira, SP, Brasil.
}

\begin{abstract}
Aims: This paper sought to evaluate the infrastructure of public swimming pools in a countryside municipality of the state of São Paulo and to present the Geographic Information System (GIS) as a tool capable of assisting in the management of sports facilities and programs. Methods: This is a descriptive study since it intends to expose the characteristics of a certain context. First, documentary research was performed to map the facilities and their respective projects. After that, a field survey was conducted seeking to evaluate the infrastructure of public pools and their surroundings through observation. Lastly, using georeferencing software, the population, and socioeconomic data around these pools were obtained and analyzed. Results: It was identified ten public swimming pools, and in seven the offer of swimming projects was foreseen. The infrastructure of the pools is mainly unsatisfactory, making necessary the improvement of the installation itself and in its surroundings. According to the results of the GIS, each pool has its specific public target concerning the characteristics of the profile of the residents surrounding these facilities. Conclusion: Information regarding the public profile around sports facilities generated from a tool such as GIS showed it is possible to determine which sports projects should be prioritized in each facility, leading to improvement in the management of sports-related public policies.
\end{abstract}

Keywords: Sports policies, Facilities management, Geographic Information System, Sports facilities.

\section{Introduction}

Due to the development of sport-specific public agencies, in addition to the large and mega-sporting events held in Brazil between 2002 and 2016, a series of studies and diagnoses on sports policies in Brazil was carried out ${ }^{1,2,3}$. Many of these studies highlighted the lack of effectiveness of public sports policies in the country, partly justified by the distance between the practical field of the implementation of public sports policies and the field of scientific research ${ }^{4}$. In addition, ineffective management of sports policies is identified in the country, evidenced by the lack of planning and specialized human resources in most of the state bodies responsible for sport ${ }^{5}$ and the construction of policies based on empiricism ${ }^{6}$. Thus, this fragile context of public sports policies in Brazil makes it emerge with greater intensity the need for new processes and tools to improve the management of sports policies in Brazil ${ }^{7}$.

Since Brazil is a large country with differing socioeconomic contexts, the adaptation of concepts and instruments used in other areas, contexts, and even countries is needed in order to allow their applicability. For European authors such as Carvalho ${ }^{8}$, good sports policies should take into account at least: (1) sports structures and facilities to develop sporting programs; (2) support or partnerships from sports organizations, such as federations, clubs, and associations for the effective occupation of spaces, and (3) pedagogically well-planned and executable programs, consistent with the reality and expectations of the target audience.

In the case of sports facilities, these structures must have good physical conditions and support space that enable sports practice to be carried out in an appropriate manner ${ }^{9,10}$. And although such good conditions are important, it is even more necessary to have a detailed knowledge of the public served by these facilities, in order to ensure the offer of sports programs more consistent with the reality of the target audience benefited.

However, there is a certain gap regarding the understanding of the target audience due to the difficulty in obtaining information about the profile of these groups, caused by the lack of instruments and research mechanisms for this purpose. Since the reality of the public around certain sports facilities is unknown, there are greater chances of failure in sports policies ${ }^{3,11}$. In possession of information regarding where these spaces for sports practice are allocated, there is still a way to plan the implementation of new sports structures in areas not benefited by one yet ${ }^{3,11}$.

Thus, it is evident that the mere existence of facilities for the practice of sport is insufficient for the success of public sports policy proposals, as a set of variables can influence the adherence of the benefited public ${ }^{9,10}$. Under- 
standing the impact caused by the presence of facilities on the population, with sports programs capable of transforming the reality of the individuals benefited by them is something to be idealized, and this is the big gap that needs to be understood and solved by public sports policies, so that the principle of sustainability is achieved, according to which:

The sports facility is sustainable when the resources necessary for its maintenance and continuous operation are foreseen and ensured, while also contributing to the increase in future opportunities for "sports for all" and the integrity of the natural environment in which it operates ${ }^{12}$.

The concept of sustainability is comprehensive, involving "sustainable development", where the objective is to make any planning of the respective program have long-lasting benefits. Thus, from the perspective of Elkington $^{13}$, sustainability must seek harmony between administrative/financial performance, social responsibility, and reflection over the environment. Any organization (public or private) must be able to use its resources more efficiently (do more with less), improve the institution's image with significant results in the social context in which it is inserted, and seek to improve its relations with other organizations ${ }^{13}$.

Thus, this study aims to propose a solution to the lack of knowledge of the public that enjoys these sports facilities, in order to guarantee the offer of sports programs more coherent with the profile of this public. That is, an option will be proposed so that public sports policy actions are more sustainable and effective.

Firstly, before the construction of new structures for sports practice, or even before planning and deciding which sports programs will be offered at the existing facilities, prior studies are necessary in order to obtain essential information for this decisions-making. In this sense, an instrument that can be used for acquiring data to achieve the complete diagnosis of a given object is the Geographic Information System (GIS), whose procedure is also known as georeferential analysis methodology. The GIS is a system that organizes spatially referenced data such as geographic location, socioeconomic data of the population of a given region, among others. The main characteristic of GIS is to analyze data for generating new information, including specific purposes ${ }^{14}$, and to solve complex planning and management problems ${ }^{15}$. Thus, data related to a series of items, such as the cost of building/maintaining new spaces, the dynamics of the population surrounding the facility, the condition and socioeconomic distribution of a population, among others, would provide a set of valuable information that would allow improving the efficiency and sustainability of public sports policy management ${ }^{3,11,16}$.

In the literature, studies using the GIS methodology and sportive facilities are found, but mainly in European countries. However, these examples present how GIS- based analyzes can be useful to investigate the distribution of sports facilities in a given region, besides to identify the variables that interfere in the access to the facilities, as well as to trace the parameters that influence the rate of sports participation and the physical activity levels of the population (such as educational, financial and geographical aspects) $)^{17,18,19}$.

A Brazilian study carried out in Vitória - ES corroborates these ideas and affirms that the use of GIS allows a rational model of public policy management ${ }^{20}$, according to which decision-making is based on data, allowing for greater, better and more assertive corporate gain ${ }^{21}$.

However, some obstacles to this instrument are the technical language and specific handling tools being, for this reason, little used in the areas of sports management and policies, where its professionals and researchers are rarely trained to be capable to use this methodology. Thus, its use can be seen as an interdisciplinary initiative (computing, public administration, urbanism, physical education, and sport) or intersectoral policy, a required action for the success of analyses, especially for the effectiveness of public policies ${ }^{16}$.

Thus, considering the exposed above, the objectives of this study were to analyze the infrastructure of public swimming pools in a municipality in the countryside of Brazil as an example of public sport policy; and to complement this analysis with the Geographic Information System (GIS), presenting it as a management tool capable of assisting in the diagnosis on the geographical location of sports facilities and the profile of the target audience served by these facilities.

\section{Methods}

\section{Methodological approach}

The methodology is characterized as descriptive, since it intends to expose and describe the characteristics of a certain phenomenon, establishing possible relationships between researched variables ${ }^{22,23}$. In this study, we sought to describe the context of public sports policies in a given municipality in the interior of Brazil, comprehending the analysis of the infrastructure of the public swimming pools, and the analysis of the profile of the public served by these facilities using the tool Geographic Information System (GIS). For Malhotra ${ }^{24}$, descriptive research is sometimes considered simpler, as it involves the characterization of a study topic without the direct objective of explaining it. On the other hand, these characterizations can also generate possible reflections and correlations between variables, serving as a basis for potential explanations of a given phenomenon ${ }^{24}$. Thus, given the characteristics of this study, it will be possible to describe and correlate some variables that influence the context of the existing sports facilities, the sports programs offered, and 
the public benefited by the actions of public sport policy. From this, new reflections can be generated, and new studies can be made from the results obtained in this descriptive research.

\section{Study object}

The municipal swimming pools of Limeira, a municipality situated in the countryside of São Paulo about 224 kilometers away from the Atlantic Ocean, were analyzed. This municipality was selected for the convenience of the researchers. However, Limeira has a relevant history concerning swimming, always occupying significant positions in state and national competitions, even being the hometown of $2(1.23 \%)$ Brazilian Olympic swimming athletes $^{25,26,27}$.

\section{Procedures and data collection}

Documentary and field research were used as methodological procedures for data collection ${ }^{23}$. The entire data collection was divided into three stages. At first, documents from public archives (laws, bills, annuals, reports, etc.) were surveyed to identify public sports facilities, projects, and public policies that enable the initiation and development of swimming in the municipality. The selection and inclusion criteria for the pools in this count were related to them being owned by the municipality, as well as their length, with only semi-Olympic ( 25 meters) or Olympic (50 meters) pools being considered for this paper. Based on this identification, a mapping of the facilities was made while also identifying which of these were expected to offer swimming projects according to the Service Charter for 2018 available on the website of the municipality's Sports Secretary ${ }^{28}$.

As a second stage, it was chosen to conduct a field survey from the mapping of the pools. In this phase, the conditions of the swimming pool infrastructure and its surroundings were evaluated to ascertain whether these facilities had satisfactory conditions for use. The observed items are shown in Table 1. In the first column are the items related to the pool itself (heating, cleaning of water and tiles) and the equipment used in the practice of swimming (starting block, backstroke flags, and lane lines),

Table 1 - Analysis factors to identify the physical conditions of pools and their surroundings. Source: own elaboration.

\begin{tabular}{ll}
\hline Pool & Surroundings \\
\hline Water cleaning & Cleaning and maintenance of the changing room \\
Water heating & Shower heating \\
Starting block & Locker \\
Backstroke flags & Accessibility to the pool and changing room \\
Swimming lane line & Swimming training equipment \\
Pool tiles & Roofed swimming pool Bleachers \\
& Bleachers \\
\hline
\end{tabular}

without which the practice is impaired. In the second column are the items related to the conditions surrounding the pools (accessibility, changing rooms, bleachers, and roofed pool), items that are also relevant to ensure the proper usability of the installation. An evaluation of these items was made classifying them from 0 to 3 as follows: 0 for Nonexistent, 1 for Poor, 2 for Satisfactory, and 3 for $\operatorname{Good}^{29}$. Classification X was also created for situations in which it was not possible to perform a consistent evaluation. Observation and classification were conducted by two researchers/authors of this article independently and later the results were compared.

Lastly, during the third stage, which demonstrates the use of GIS, data were collected on the socioeconomic and population profile of the public residing around the identified pools. In this step, ArcMap, a GIS software application from the set of geospatial processing programs ArcGIS from the company Esri ${ }^{30}$ was used. Geospatial data were cross-referenced regarding the location of the facilities identified with the municipality's data grid, provided by the Municipal Secretary of Urbanism from Limeira, referring to the year 2010, the year in which the last Demographic Census was carried out by the Brazilian Institute of Geography and Statistics ${ }^{31}$, with the next scheduled for 2020. In more detail, the data selected for the analysis of this stage were divided into Categories with their respective Factors (Table 2).

\section{Data analysis}

The analysis of the data obtained in the third stage of the study was carried out by crossing the data referring to the location of the pools and the data grid in the municipality of Limeira - SP. For this analysis, a coverage area with a radius of 1 kilometer was stipulated from each public swimming pool identified. Although there is a lack of consensus on the appropriate buffer size (coverage area) to measure possible associations between population char-

Table 2 - Categories and factors of georeferential analysis. Source: own elaboration.

\begin{tabular}{ll}
\hline Categories & Factors \\
\hline Population & $\begin{array}{l}\text { Number of inhabitants } \\
\text { Number of neighborhoods covered }\end{array}$ \\
Education & $\begin{array}{l}\text { Number of public schools } \\
\text { Number of private schools }\end{array}$ \\
Health & $\begin{array}{l}\text { Number of health agencies } \\
\text { Social Vulner- }\end{array}$ \\
ability & $\begin{array}{l}\text { Ranking in the São Paulo Social Vulnerability Index } \\
\text { (IPVS) }\end{array}$ \\
& $\begin{array}{l}\text { Average wage income per capita } \\
\text { Proportion of children aged 0 to 5 years in the popu- } \\
\text { lation }\end{array}$ \\
\hline
\end{tabular}


acteristics and the practice of physical activity, this theme has been the focus of several more recent studies ${ }^{32,33}$.

Of the categories and their respective analysis factors listed, it is worth noting that in the Population, Education, and Health categories, absolute values were collected. Regarding the Social Vulnerability category, the factor "Ranking in the São Paulo Social Vulnerability Index" (Índice Paulista de Vulnerabilidade Social - IPVS) is a synthetic indicator that classifies all census sectors in the state of São Paulo into 8 groups: Unclassified (0); Lowest (1); Very low (2); Low (3); Medium (4); High (5, for urban centers); Very high (6) and High (7, for rural centers $)^{34}$. Thus, the data presented in this factor are fashion statistical values, that is, the most frequent values within a data $\operatorname{set}^{35}$. This was used because within the area covered by the pools there are places with greater social vulnerability and others with less, and as such we opted for the presentation of the most frequent values. Furthermore, the factors "Proportion of children aged 0 to 5 years in the population" and "Average wage income per capita" are median statistical values. We chose to use the median since it is recommended to use it when the dataset does not follow a normal distribution or when there are discrepant data within this set ${ }^{35}$. The proportion of children is presented in percentage, and relative to the population of the census region.

\section{Results}

The documentary survey resulted in the identification of ten (10) public-type swimming pools under municipal management. Of these, nine (9) are 25 -meter semiOlympic pools and only one (1) is a 50-meter Olympic pool. The identified pools were named by the letters A, B, $\mathrm{C}, \mathrm{D}, \mathrm{E}, \mathrm{F}, \mathrm{G}, \mathrm{H}$ and I, in order to facilitate the presentation of results and discussion. As a note, the place indicated by the letter D includes two swimming pools, the first being semi-Olympic (D1) and the other being Olympic (D2). Regarding activities, in 7 the offer of swimming projects was foreseen, mostly sports initiation and participation for children and young people, and in the other 3, there was no specification on the offer of sports projects. These data and information are presented in Figure 1. The location of the pools is well distributed geographically throughout the municipality, which in theory ensures that most citizens have access to sports projects.

In this sense, a possible hypothesis to justify why in some pools there was the offer of projects for the practice of swimming and others there was not, would be in relation to the conditions, adequate or not, of the infrastructure of these spaces. Thus, as this study also aimed to analyze the infrastructure of these municipal public pools, field research was performed in order to verify whether the

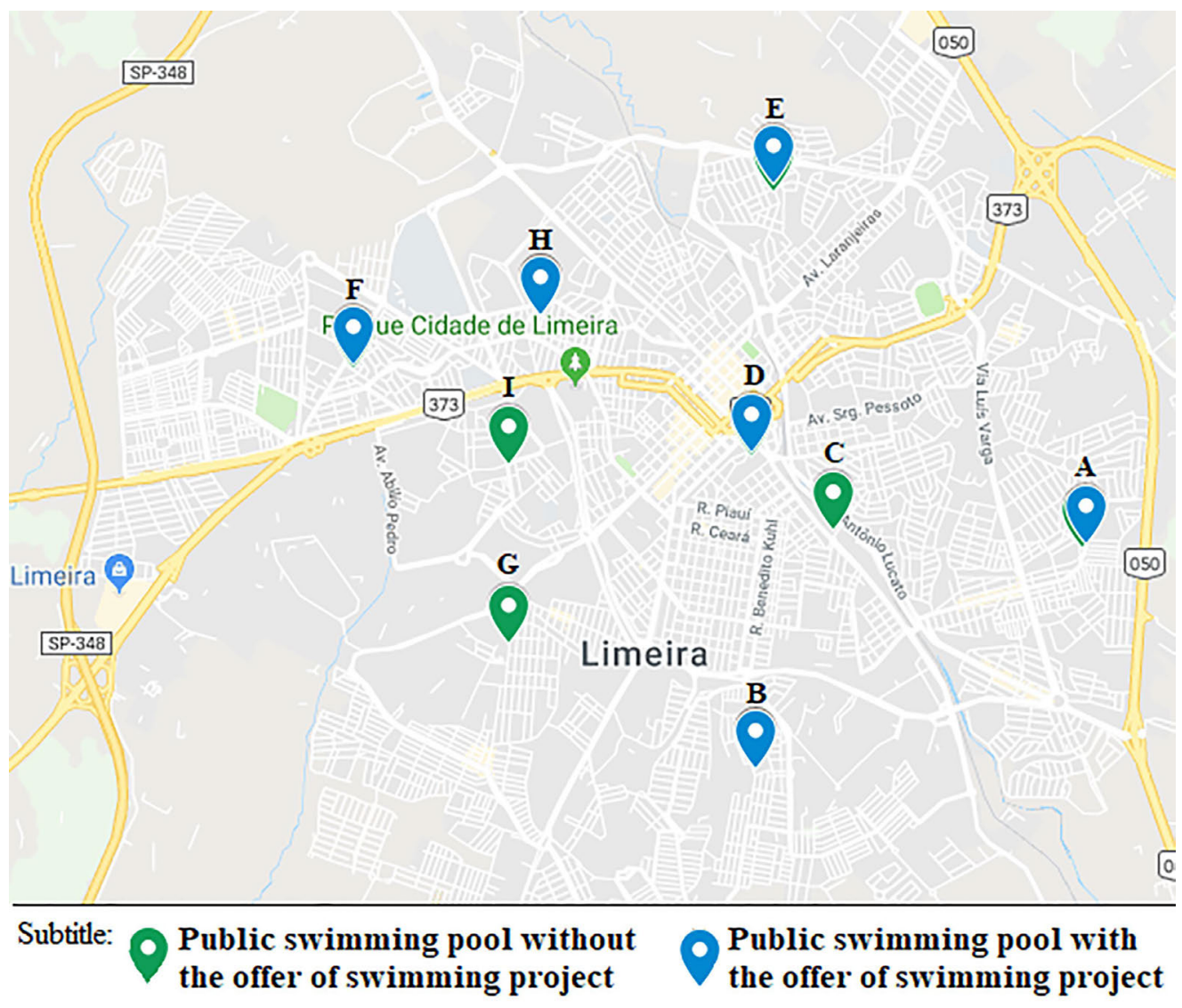

Figure 1 - Location of public swimming pools in the municipality of Limeira, SP. Source: own elaboration. 
pools are suitable for the practice of the sport. The results of this observation are shown in Table 3.

The data in this table shows that of the ten public swimming pools, only one has a satisfactory physical condition level (swimming pool D1). All the others were found to be poor mainly due to the absence and the precarious conditions of water heating, accessibility, swimming training equipment, backstroke flags, roofed swimming pool and bleachers in most of the pools verified. And although the practice of swimming is offered in $70 \%$ of public pools, all have points in their infrastructure

Table 3 - Infrastructure conditions for public swimming pools in Limeira, SP. Source: own elaboration.

\begin{tabular}{|c|c|c|c|c|c|c|c|c|c|c|}
\hline Pool & $\mathbf{A}$ & B & $\mathbf{C}$ & D1 & D2 & $\mathbf{E}$ & $\mathbf{F}$ & $\mathbf{G}$ & $\mathbf{H}$ & I \\
\hline Water cleaning & 2 & 3 & 3 & 3 & 1 & 3 & 3 & 1 & 2 & 2 \\
\hline Water heating & 0 & 0 & 3 & 2 & 0 & 0 & 0 & 0 & 2 & 0 \\
\hline Starting block & 3 & 1 & 0 & 2 & 2 & 1 & $\mathrm{x}$ & 1 & 1 & 1 \\
\hline Backstroke flags & 0 & 0 & 0 & 3 & 2 & 0 & 0 & 0 & 2 & 0 \\
\hline Swimming lane line & 3 & 0 & 2 & 2 & 2 & 0 & 0 & 3 & 3 & 2 \\
\hline Pool tiles & 3 & 5 & 3 & 3 & 1 & 3 & $\mathrm{x}$ & 2 & 3 & 2 \\
\hline $\begin{array}{l}\text { Changing room infra- } \\
\text { structure }\end{array}$ & 3 & $\mathrm{x}$ & 2 & 2 & 2 & 3 & $\mathrm{x}$ & 3 & 2 & 3 \\
\hline Shower heating & 2 & $\mathrm{x}$ & 3 & 1 & 1 & 1 & $\mathrm{x}$ & 0 & 2 & 2 \\
\hline Locker & 0 & $x$ & 2 & 0 & 0 & 0 & $\mathrm{x}$ & 0 & 0 & 0 \\
\hline Accessibility & 2 & 1 & 2 & 1 & 1 & 2 & 1 & 2 & 2 & 2 \\
\hline $\begin{array}{l}\text { Swimming training } \\
\text { equipment }\end{array}$ & 0 & 0 & 2 & 2 & 2 & 0 & 0 & 0 & 2 & 0 \\
\hline $\begin{array}{l}\text { Roofed swimming } \\
\text { pool }\end{array}$ & 0 & 0 & 3 & 3 & 0 & 0 & 0 & 0 & 0 & 0 \\
\hline Bleachers & 0 & 0 & 0 & 2 & 2 & 0 & 0 & 0 & 0 & 0 \\
\hline Pool average & 1.4 & 1.0 & 1.9 & 2.0 & 1.2 & 1.0 & 0.5 & 0.9 & 1.6 & 1.1 \\
\hline
\end{tabular}

that can and should be improved, both in the installation itself and in its surroundings to ensure that the usability of the pools is greater.

Lastly, the results on the population and socioeconomic profile of citizens living in the vicinity of these facilities can be seen in Table 4, obtained from the crossing of the data in Table 2. This table shows that the least populated pool reaches 8,876 inhabitants and 38 neighborhoods, while the most populous one covers 23,309 inhabitants and 25 neighborhoods. The average number of inhabitants who attended the pools would be 14,289. Educational data show that the distribution of schools is not equitable, since the numbers vary from 4 (pool G) to 37 schools (pool D), and only in pools C and D the number of private schools exceeds the number of public schools. This unequal distribution also occurs in the number of health agencies, which vary between 1 (pool G) and 11 (pool C) organs around these 9 public pools.

In the Social Vulnerability category, most pools are classified as Very Low according to the São Paulo Social Vulnerability Index (IPVS), except for A which is considered of Medium Vulnerability, indicating that this pool may have a greater focus by public sports policies. In the factors "Ranking in the São Paulo Social Vulnerability Index (IPVS)" and "Average wage income per capita", Table 4 provides the values of mode and median, respectively. However, in a more detailed analysis containing the standard deviations of each pool for these factors, the results show that about the social vulnerability only A, B and $\mathrm{F}$ have more vulnerable regions than others within their respective areas of coverage, while the other pools have less discrepant values of social vulnerability (Figure 2).

Such analysis can also be done with pools D and $\mathrm{H}$ with respect to income distribution, with people with much higher wage income and others much lower than the

Table 4 - Results of georeferential analysis factors for each pool. Source: own elaboration.

\begin{tabular}{|c|c|c|c|c|c|c|c|c|c|c|}
\hline \multirow[t]{2}{*}{ Categories } & \multirow[t]{2}{*}{ Factors of analysis } & \multicolumn{9}{|c|}{ Swimming pools } \\
\hline & & $\mathbf{A}$ & B & $\mathbf{C}$ & D & $\mathbf{E}$ & $\mathbf{F}$ & $\mathbf{G}$ & $\mathbf{H}$ & $\mathbf{I}$ \\
\hline \multirow[t]{2}{*}{ Population } & Number of inhabitants & 23309 & 20832 & 15136 & 13956 & 12966 & 12614 & 11475 & 9433 & 8876 \\
\hline & Number of neighborhoods covered & 25 & 31 & 51 & 33 & 29 & 33 & 29 & 33 & 38 \\
\hline \multirow[t]{2}{*}{ Education } & Number of public schools & 10 & 9 & 7 & 12 & 5 & 7 & 3 & 6 & 4 \\
\hline & Number of private schools & 0 & 1 & 11 & 25 & 2 & 5 & 1 & 7 & 1 \\
\hline Health & Number of health agencies & 4 & 2 & 11 & 10 & 2 & 3 & 1 & 2 & 3 \\
\hline \multirow[t]{3}{*}{ Social Vulnerability } & Ranking in the São Paulo Social Vulnerability Index (IPVS) & 4 & 2 & 2 & 2 & 2 & 2 & 2 & 2 & 2 \\
\hline & Average wage income per capita (R\$) & 558,6 & 573,6 & 928,2 & 1291 & 756,9 & 683,3 & 689,3 & 1053 & 993,3 \\
\hline & Proportion of children aged 0 to 5 years in the population & 8 & 8 & 5 & 4 & 6 & 7 & 7 & 5 & 5 \\
\hline
\end{tabular}




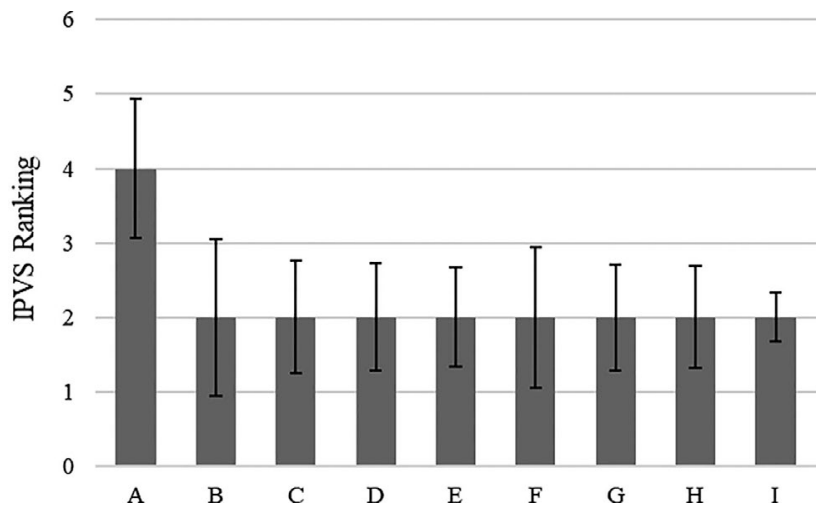

Figure 2 - IPVS Ranking and its respective standard deviations regarding the surroundings of each public swimming pool in the municipality of Limeira, SP. Source: own elaboration.

median of individuals in that area, indicating great inequality in economic distribution (Figure 3).

Concerning the proportion of children, it was diverse and varied between 4.22 and 8.01, allowing sports projects aimed at the initiation of sports for children to be offered in swimming pools where this proportion is higher. Economic data also has a very varied distribution, with an average income per capita ranging between $\mathrm{R} \$ 558.57$ and $\mathrm{R} \$ 1,291.10$.

\section{Discussion}

Considering the objective of presenting the sports facilities present in the municipality and the sports projects offered in them, it was noted that the pools mapped are well geographically distributed, in order to guarantee, in theory, that the majority of the population has access to public policies involving these facilities. Indeed, studies claim that the shorter the distance between the individual's residence and the sports facility, the greater the likelihood that they will practice sports ${ }^{36}$. This association is even stronger when access to a swimming pool is between

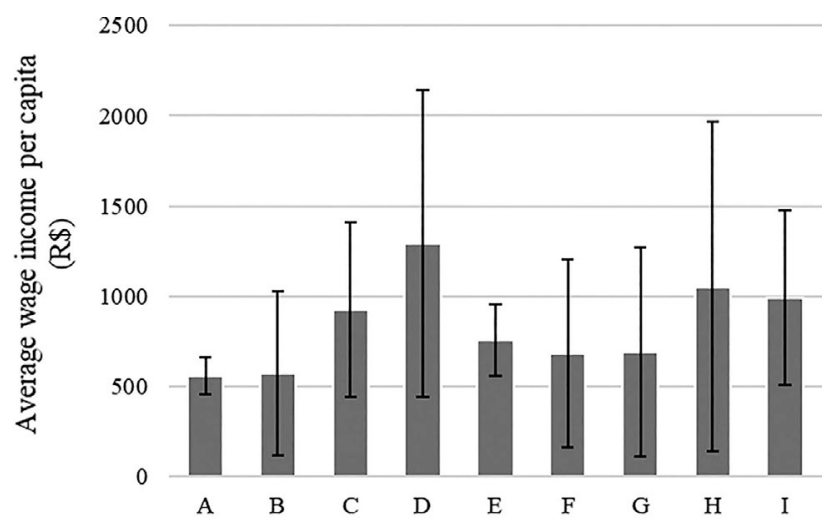

Figure 3 - Average wage income per capita and its respective standard deviations relative to the surroundings of each public swimming pool in the municipality of Limeira, SP. Source: own elaboration.
$900 \mathrm{~m}$ and $1000 \mathrm{~m}$ from the residence, while greater distances would cause low regularity in the use of the facili$\operatorname{ties}^{19}$. However, it is assumed that swimming pools where there are not sports projects being offered also fail to serve and benefit part of the population. So, it is understood that despite the existence of sports facilities, it is necessary to constantly offer sports projects in these spaces, as its promotion, in order to ensure that the entire population has access to and knowledge of the sports practices offered $^{3,7,11}$. The mapping of facilities would be the beginning of the implementation of any public policy, but ironically, this type of action is uncommon in Brazilian sports policies ${ }^{37}$. This lack of diagnosis occurs for different reasons, but there is the complexity that involves sport in the country, divided into state power (municipal, state and federal) and the private sector (associations, clubs, $\mathrm{S}$ system, etc. $)^{37,38}$.

This article also aimed to analyze the physical conditions of the facilities, certifying whether they are appropriate or not for the practice of swimming. In this sense, regarding the quality of these infrastructures, by the results identified, it is evident that more care and efforts are needed by public authorities for these facilities, considering that the biggest majority of the pools and its surroundings present poor conditions. For the practice of sports to be performed properly and for sports projects to have greater adherence, the physical conditions of safety, accessibility, and sports practice must be minimally satisfactory. In fact, a study pointed out that pool heating is one of the most relevant items with regard to the usability of a pool, demonstrating that adequate water temperature increases the chances of the pool being used ${ }^{19}$. Despite the municipality's climate presents tropical characteristics for most of the year, $70 \%$ of the assessed pools do not have water heating.

In addition, this information about the characteristics of the infrastructures is as relevant as the data on the population and socioeconomic profile served by a facility when it aims to propose an intervention or a sports program. This is because, as much as the characteristics of the target audience are known, if the physical conditions of the pool are precarious, these actions are unlikely to be successful ${ }^{39}$. In this sense, studies point to the need for more research to assess the physical characteristics of sports facilities, showing whether there is, for example, accessibility for groups of people with disabilities, the presence of changing rooms / heated showers, coverage, bleachers, etc. Thus, such information could and should be incorporated into GIS analyzes, enabling better assessments to be made of the quality of the sports services offered $^{17,18}$.

Thus, the main objective of this study was to present the GIS as a tool for a more robust diagnostic analysis of public sports facilities, providing better management of these policies from obtaining data related to the population 
and socioeconomic profile of the individuals served. So, taking into account the information obtained by the GIS, assumedly there is an audience with specific characteristics in each pool and consequently also the potential to offer different projects that are more coherent with such particularities. Such specific characteristics, both of the target audience and the conditions of the facilities infrastructure must be known by the agents of the public power responsible for the formulation of public sports policies and the sports management of the municipality. In possession of this information, the public manager would be greatly assisted in deciding which sports projects should be offered, seeking greater coherence with the characteristics of each target audience ${ }^{21}$.

It is intended from this point on to exemplify with practical situations the use of GIS as a highly capable instrument to elucidate decision making by the sports manager. Thus, based on the data presented, a particular discussion can be drawn about the characteristics of sports projects that could now be analyzed, prioritizing each location, the characteristics of each installation, and taking into account the profile of the target audience served by each one. As an example, we can mention the case of pools $\mathrm{A}$ and $\mathrm{B}$, located on the outskirts of the city, which are extremely populous and populated and present a large number of children in its population, low economic power (represented by low wage income and only one private school) and medium-high social vulnerability. These two pools deserve a closer look due to the conditions of social inequality, wherein mostly children's swimming projects can be offered - considering that this sport is an important promoter of social inclusion, and allows children and adolescents to develop in a healthy way ${ }^{40,41}$. Another example is that of swimming pool $\mathrm{D}$, whose general region shows a large number of schools, and as such investments in educational sports projects in partnership with these schools could be made.

Following this discussion, it is observed that the swimming pools where there is no offer of sports programs (pools $\mathrm{C}, \mathrm{G}$, and $\mathrm{I}$ ) also have their particularities. $\mathrm{C}$ has a large number of health agencies, in addition to a high average wage income per capita, and one of the lowest proportions of children in the population, which would favor the offer of sports projects for the older population, for instance. Pool G, on the other hand, has the secondhighest proportion of children while only having four schools in its surroundings, which suggests that the provision of sports initiation projects for children may be successful, as it is a healthy option to fill the leisure time of these children on weekends.

Lastly, regarding pool I, although it covers the smallest number of inhabitants, as it is located in a more central region of the city and has one of the highest values of wage income, it could be used for projects aimed at the development of young people who have the intention and potential to achieve high sports performance in the future. For the structuring of a municipal sports system linked to swimming to be successful, it must have transportation and other types of support to allow the development of young people interested in pursuing a sports career ${ }^{42}$.

Therefore, with the analysis of public swimming pools and the data acquired with the GIS instrument, combined with other information pertinent to the referred sport, an interesting possibility becomes available for the use of a tool like this, able to ensure a better understanding of the location of sports facilities and the population profile attended by facilities and sports projects. In possession of this information, more coherent management of sports programs from the government can be achieved ensuring the statement by Carvalho ${ }^{8}$ that a good sports policy must comprise pedagogically well-planned and executable programs, consistent with the reality and expectations of the target audience.

Another use of GIS would be the visualization of a system or network. As pointed out by different authors in the last few years, one of the great problems of Brazilian sport has been the absence of a sports system, which includes sports initiation, development, and performance. There is an absence of a transparent system where the population has access to sport, that is, public sports policies are lacking, be them for education, participation, or high-performance ${ }^{1,3,7,43,44}$. With the GIS, the system can appear on a national level, forming a network of systems and facilitating their possible connections in a "bottomup" approach ${ }^{45}$ for sports development.

More detailed analyzes of the georeferencing results can and should be applied in other facilities of other sports, seeking a better understanding of the population and the socioeconomic characteristics of the citizens in the municipality. Obtaining information about the physical conditions of sports facilities, the offer of sports projects, and the demand of the target audience would ensure more effective sports policies, as recommended by authors of this field ${ }^{1,3,8}$. This idea is also reinforced by Starepravo and Marchi Júnior ${ }^{46}$, who affirm that the study of public policies presupposes the mapping of the social space where it is performed, the understanding of the relationships between the agents involved with the policy and the understanding of which policies were carried out or not.

On the other hand, the GIS system may come with limitations as is the case with its use in small municipalities, where a logical solution for the lack of sports structures is not possible, which has already been pointed out as a characteristic of most Brazilian cities ${ }^{47}$. Another limitation is the need for knowledge of its technique as well as its interdisciplinary and intersectoral need. For instance, the use of the GIS would provide more effective results when used in metropolitan regions, in partnership with different municipalities and their respective varieties of public sector bodies ${ }^{48}$. In addition to these, as discussed 
in this study, there is also a limitation of the GIS in not providing information about the characteristics of physical conditions of sports facilities, so that these must be obtained through field research. Finally, as a general limitation of this study, it focused only on one type of facility, those from a specific municipality. Future studies should deepen and expand the use, both of GIS, and of other tools that favor the better management of public policies with sport in Brazil.

\section{Conclusions}

In recent years, there has been an increase in the recognition and need in the field of management applied to sports, especially within the scope of public policies. Researchers and managers face the challenge of developing processes that provide better management of their actions.

Among the many existing tools, a descriptive diagnosis combined with a management tool such as the Geographic Information System (GIS) can help substantially in the better management of existing sports facilities in a municipality and the proper idealization and development of projects that should be implemented in the respective sports facilities.

Since the GIS is a tool handled by technical professionals, its use must be interdisciplinary and of intersectoral nature, as advocated as a proposal for the improvement of public service in Brazil. The use of tools such as GIS is an option in the search for better use of resources, aiming for the sustainability of projects and programs linked to public policies.

\section{References}

1. Böhme MTS, Bojikian LP, Massa M, Lima MR. Sistemas de identificação e desenvolvimento de talentos. In: Böhme MTS, Bastos FC, eds. Esporte de Alto Rendimento: Fatores Críticos - Gestão - Identificação de Talentos. São Paulo, Phorte Editora; 2016. p. 147-173.

2. Brasil - Tribunal de Contas da União. Relatório de Auditoria Operacional: Esporte de Alto Rendimento. Brasília: TCU, Secretaria de Fiscalização e Avaliação de Programas de Governo, 2011.

3. Mezzadri FM. Políticas Públicas e Esporte. Várzea Paulista: Editora Fontoura, 2014.

4. Starepravo FA. Políticas públicas de esporte e lazer no Brasil. 2011;17(August 2011). doi:10.13140/RG.2.2.27487.46242

5. de Souza DL, Mezzadri FM, Cavichiolli FR. Esporte e Lazer: Subsídios Para o Desenvolvimento e Gestão de Políticas Públicas. (de Souza DL, Mezzadri FM, Cavichiolli FR, eds.). Jundiaí, Editora Fontoura; 2006.

6. Cavichiolli FR. Políticas públicas para o esporte e lazer: tentativa de mudanças. 1996.
7. Mazzei LC, Rocco Júnior AJ. Um ensaio sobre a Gestão do Esporte: um momento para a sua afirmação no Brasil. Rev Gestão e Negócios do Esporte. 2017;2(1):96-109.

8. Carvalho MJ. O desporto como matéria de interesse público: da lei à realidade. In: XV Congresso de Ciência Do Desporto e Educação Física Dos Países de Língua Portuguesa. Mesa Temática de Lazer: Políticas Públicas e Sociedade. Recife, Revista Portuguesa de Ciências do Desporto, 2014.

9. Ribeiro FT. Novos Espaços Para Esporte e Lazer. São Paulo, Ícone Editora, 2011.

10. Schwarz EC, Hall SA, Shibli S. Facility marketing management. In: Schwarz EC, Hatt SA, Shlbli S, eds. Sport Facility Operations Management. London, New York, Routledge, 2012. p. 155-170.

11. Isayama HF, Magalhães Pinto LMS, Uvinha RR, Stoppa EA, eds. Gestão de Políticas de Esporte e Lazer: Experiências, Inovações, Potencialidades e Desafios. Belo Horizonte, Editora UFMG, 2011.

12. Ribeiro FT. Legado de Megaeventos Esportivos Sustentáveis: A Importância das Instalações Esportivas. In: Lamartine PDC, Corrêa D, Villano ERB, Miragaya A, eds. Legados de Megaeventos Esportivos. Brasilia, Ministério do Esporte, 2008. p. 107-116.

13. Elkington J. Cannibals with Forks: The Triple Bottom Line of 21 st Century Business. Gabriola Island, New Society Publishers, 1998.

14. Parent PJ. Geographic Information Systems: Evolution of Academic Involvement and Issues Arising from Proliferation Os Information. Santa Barbara, University of California, 1988.

15. Cotter D, Gibson R, Liston R, Tom H, Trainor T, VanWyhe HP. A Process for Evaluating Geographical Information Systems. Guptill, 1988.

16. Cunha LM. Os Espaços Do Desporto: Uma Gestão Para o Desenvolvimento Humano. Coimbra, Almedina, 2007.

17. Billaudeau N, Oppert J, Simon C, Charreire H, Casey R, Salze $\mathrm{P}$, et al. Investigating disparities in spatial accessibility to and characteristics of sports facilities?: Direction, strength, and spatial scale of associations with area income. Health Place. 2011;17:114-121. doi:10.1016/j.healthplace.2010.09.004

18. Higgs G, Langford M, Norman P. Accessibility to sports facilities in Wales: A GIS-based analysis of socioeconomic variations in provision. Geoforum. 2015;62:105-120. doi:10.1016/j.geoforum.2015.04.010

19. Karusisi N, Thomas F, Méline J, Chaix B. Spatial accessibility to specific sports facilities and corresponding sports practice?: the RECORD Study. Int J Behav Nutr Phys Act. 2013;10(48). doi:10.1186/1479-5868-10-48

20. Dye TR. Models Of Politics: Some Help In Thinking About Public Policy. In: Understanding Public Policy. 11th ed. New Jersey, Prentice-Hall; 2005.

21. Camargo LP, Belem CM. Sistema de Informação Geográfica como metodologia de avaliação de políticas públicas de saúde: o caso do SOE. Rev Intercont Gestão Desportiva. 2018;8(3):75-95.

22. Creswell JW. Projeto de Pesquisa: Métodos Qualitativos, Quantitativo e Misto. 3rd ed. Porto Alegre, Artmed, 2010. 
23. Vergara SC. Projetos e Relatórios de Pesquisa Em Administração. 12 $2^{\mathrm{a}}$ ed. São Paulo, Editora Atlas, 2010.

24. Malhotra NK. Pesquisa de Marketing - Foco Na Decisão. $3^{\mathrm{a}}$. São Paulo, Pearson Brasil, 2011.

25. Ferreira E. Natação de Limeira é vice-campeã dos Jogos Regionais. Rápido no Ar. Available from: https://www.rapi donoar.com.br/natacao-de-limeira-e-vice-campea-dosjogos-regionais/ [Accessed $27^{\text {th }}$ July 2019].

26. Wikipédia. Natália de Luccas. Flórida: Wikimedia Foundation. Available from: https://pt.wikipedia.org/w/index.php? title=Natalia_de_Luccas\&oldid $=55078399$. [Accessed $5^{\text {th }}$ August 2019].

27. Wikipédia. Guilherme Guido. Flórida: Wikimedia Foundation Available from:. https://pt.wikipedia.org/w/index.php? title $=$ Guilherme_Guido\&oldid $=56575294$. [Accessed $5^{\text {th }}$ August 2019].

28. Secretaria de Esporte e Lazer. Carta de Serviços. Prefeitura Municipal de Limeira. Available from: https://www.limeira. sp.gov.br/sitenovo/hotsite.php?id=4. [Accessed $2^{\text {nd }}$ October 2018].

29. Bruner II GC. Service Quality (Physical Aspects of Facility). In: Marketing Scales Handbook: A Compilation of Multi-Item Measures for Consumer Behavior \& Advertising Research. Texas, GCBII Productions; 2012. p. 620.

30. ESRI A. ArcMap. 2019. Available from: http://desktop.arc gis.com/en/arcmap/.

31. IBGE. Censo Demográfico 2010. Características da População e dos Domicílios. Inst Bras Geogr e Estatística, 2010.

32. James P, Berrigan D, Hart JE, Hipp JA, Hoehner CM, Kerr $\mathrm{J}$, et al. Effects of buffer size and shape on associations between the built environment and energy balance. Heal Place. 2014;27:162-170. doi:10.1016/j.healthplace.2014.02.003

33. Prins RG, Pierik F, Etman A, Sterkenburg RP, Kamphuis CBM, van Lenthe FJ. How many walking and cycling trips made by the elderly are beyond commonly used buffer sizes: Results from a GPS study. Heal Place. 2014;27:127133. doi:10.1016/j.healthplace.2014.01.012

34. Governo Aberto. IPVS - Índice Paulista de Vulnerabilidade Social. Available from: http://catalogo.governoaberto.sp. gov.br/dataset/21-ipvs-indice-paulista-de-vulnerabilidadesocial. [Accessed 23rd November 2018]

35. Bussab W de O, Morettin PA. Estatística Básica. $7^{\mathrm{a}}$ ed. São Paulo, Editora Saraiva, 2011.

36. Shrestha S, Kestens Y, Thomas F, El Aarbaoui T, Chaix B. Spatial access to sports facilities from the multiple places visited and sports practice: Assessing and correcting biases related to selective daily mobility. Soc Sci Med. 2019;236 (February 2018):112406. doi:10.1016/j.socscimed.2019.112406

37. Mazzei LC, Amaral CMS. Estruturas para treinamento e competições (instalações esportivas). In: Böhme MTS, Bastos FC, eds. Esporte de Alto Rendimento: Fatores Críticos, Gestão e Identificação de Talentos. São Paulo, Phorte Editora; 2016. p. 197-215.
38. Mazzei LC, Meira TB, Bastos FC, Böhme MTS, de Bosscher V. High-performance sport in Brazil Structure and policies comparison with the international context. Gest y Polit Publica. 2015;2015.

39. Silva MC da, Silva ÂB da, Amorin TEC. Condições De Espaços Públicos Destinados a Prática De Atividades Físicas $\mathrm{Na}$ Cidade De Pelotas/Rs/Brasil. Rev Bras Atividade Física Saúde. 2012;17(1):28. doi:10.12820/rbafs. v. $17 \mathrm{n} 1 \mathrm{p} 28-32$

40. De Rycke J, De Bosscher V. Mapping the potential societal impacts triggered by elite sport: a conceptual framework. Int J Sport Policy Polit. 2019;11(3):485-502. doi:10.1080/ 19406940.2019.1581649

41. Neto EDC, Dantas MMC, Maia EMC. Benefícios dos projetos sociais esportivos em crianças e adolescentes. Saúde Transform Soc. 2015;6(3):109-117.

42. Silva Filho FJ, Meira TB, Mazzei LC, Bastos FC, Böhme MTS. Sports talents in judo and swimming. Rev Bras Educ Física e Esporte. 2016;30(3):627-636.

43. União B-T de C da. Relatório de Auditoria Operacional: Esporte de Alto Rendimento. Brasília: TCU, Secretaria de Fiscalização e Avaliação de Programas de Governo; 2011.

44. Ferreira RM, Penna EM, Costa VT da, Moraes LCC de A. Nadadores medalhistas olímpicos: contexto do desenvolvimento brasileiro. Mot Rev Educ Física. 2012;18(1):130142. doi:10.1590/S1980-65742012000100014

45. Tonshoff S, Weida A. Where Top-down, Where BottomUp? Bern: Peter Lang Publishing Group, 2008.

46. Starepravo FA, Marchi Júnior W. (Re) pensando as políticas públicas de esporte e lazer: a sociogênese do subcampo político/burocrático do esporte e lazer no Brasil. Rev Bras Ciências do Esporte. 2016;38(1):42-49.

47. IBGE. Perfil Dos Estados e Dos Municípios Brasileiros Esporte. Rio de Janeiro: Instituto Brasileiro de Geografia e Estatística - IBGE, 2017.

48. Januário C, Sarmento P, Carvalho MJ. Políticas públicas desportivas: avaliação do nível de execução e eficácia nos municípios da Área Metropolitana do Porto. Rev Port Ciências do Desporto. 2009;9(2):26-32.

\section{Corresponding author}

Bruna Lindman Bueno. Address: 1300 Pedro Zaccaria st, Jardim Santa Luiza, Room LA-525D, Limeira, São Paulo, SP, Brazil.

E-mail: buenolbruna@gmail.com.

Manuscript received on February 7, 2020

Manuscript accepted on April 28, 2020

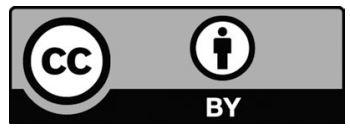

Motriz. The Journal of Physical Education. UNESP. Rio Claro, SP, Brazil - eISSN: 1980-6574 - under a license Creative Commons - Version 4.0 